\section{Physical activity indicators in adults from a state capital in the South of Brazil: a comparison between telephone and face-to-face surveys}

\author{
Indicadores da atividade física em adultos de \\ uma capital do Sul do Brasil: comparação entre \\ pesquisas telefônicas e face a face \\ Indicadores de actividad física en adultos de \\ una capital del sur de Brasil: comparación entre \\ encuestas telefónicas y cara a cara
}

Giovâni Firpo Del Duca 1 Markus Vinicius Nahas 1 Diego Augusto Santos Silva 1 Pedro Curi Hallal 2 Deborah Carvalho Malta 3 Marco Aurélio Peres 4

\author{
1 Programa de Pós-graduação \\ em Educação Física, \\ Universidade Federal de \\ Santa Catarina, Florianópolis, \\ Brasil. \\ 2 Programa de Pós-graduação \\ em Educação Física, \\ Universidade Federal de \\ Pelotas, Pelotas, Brasil. \\ 3 Secretaria de Vigilancia em \\ Saúde, Ministério da Saúde, \\ Brasília, Brasil. \\ ${ }_{4}$ Australian Research Centre \\ for Population Oral Health, \\ University of Adelaide, \\ Adelaide, Australia. \\ Correspondence \\ G. F. Del Duca \\ Programa de Pós-graduação \\ em Educação Física, \\ Universidade Federal de Santa \\ Catarina. \\ Coordenadoria de Pós- \\ graduação em Educação \\ Física, Campus Universitário \\ Reitor João David Ferreira \\ Lima, Florianópolis, SC \\ 88040-900, Brasil. \\ gfdelduca@gmail.com
}

\begin{abstract}
The aim of this study was to compare estimates of prevalence of physical activity indicators and associated sociodemographic factors obtained from telephone and face-to-face interviews with adults. Data from a cross-sectional populationbased survey of adults living in Florianópolis, Santa Catarina State, Brazil was compared to data collected through the telephonic system VIGITEL. There was no significant difference between the results from telephone interviews ( $n=$ $1,475)$ and face-to-face interviews $(n=1,720)$ with respect to prevalence of sufficient leisure time physical activity (19.3\% versus $15.5 \%$, respectively), sufficient leisure time and/or commuting physical activity (35.1\% versus $29.1 \%$, respectively) and physical inactivity (16.2\% versus $12.6 \%$, respectively). Some differences were observed with respect to the sociodemographic factors associated with leisure time and/or commuting physical activity and physical inactivity. The two techniques yielded generally similar results with respect to prevalence and sociodemographic factors associated to physical activity indicators.
\end{abstract}

Motor Activity; Self Report; Interview; Telephone

\section{Resumo}

O objetivo do estudo foi comparar as prevalências de indicadores da atividade física e fatores sociodemográficos associados de pesquisas por entrevista telefônica e face a face. Dados de pesquisa transversal de base populacional com adultos de Florianópolis, Santa Catarina, Brasil, foram confrontados com aqueles coletados pelo sistema telefônico VIGITEL. As pesquisas por entrevista telefônica $(n=1.475)$ e entrevista face a face $(n=1.720)$ não apresentaram diferenças significativas nas prevalências de atividade física suficiente no lazer (19,3\% vs. 15,5\%), atividade física suficiente no lazer e/ou deslocamento (35,1\% vs. $29,1 \%)$ e inatividade física $(16,2 \%$ vs. $12,6 \%)$, respectivamente. Na investigação dos fatores sociodemográficos associados à atividade física no lazer e/ou deslocamento e inatividade física, algumas diferenças entre as pesquisas foram observadas. Conclui-se que a maioria das estimativas de prevalências e fatores associados aos diferentes indicadores da atividade física foi semelhante entre as duas pesquisas.

Atividade Motora; Autorrelato; Entrevista; Telefone 


\section{Introduction}

The absence of a gold-standard measure for diagnosis and monitoring of physical activity has led to the use of a variety of methodologies. Objective devices such as accelerometers and pedometers ensure greater accuracy, but are more difficult to use and more expensive than questionnaires 1 . However, self-report questionnaires also present certain limitations such as the overestimation of physical activity by participants 2 .

One of the most commonly used procedures for data collection are face-to-face interviews 3,4 and self-administered questionnaires 5,6. Telephone interviews are a low-cost method of data collection, especially in high income countries where practically the entire population has access to a telephone service. The Behavioral Risk Factor Surveillance System (BRFSS) 7 is a well known monitoring system which has been updated annually since 1984 to monitor health conditions and risk behavior, including physical inactivity during leisure time ${ }^{8}$. Created by the Centers for Disease Control and Prevention (CDC), the system collects data from adults through landline and cell phone interviews in all 50 US states as well as the Districts of Columbia, Guam, Porto Rico and the Virgin Islands. Telephonic surveys have also been successfully experimented in other developed countries such as Spain ${ }^{9}$ and Israel 10 .

In middle-income countries such as Brazil, the use of telephone interviews is a relatively recent phenomenon. In 2006, an annual survey of the frequency and distribution of the main determinants of chronic non-communicable diseases in Brazilian state capitals and Federal District was initiated through the Surveillance System of Protective and Risk Factors for Chronic Diseases Telephone Survey (VIGITEL) 11. Physical activity has been measured in a number of different ways including frequency of physical activity during leisure time, physical inactivity and, more recently, sufficient leisure time and/or commuting physical activity 12 .

Although the physical activity assessment tools used in Brazil appear to be reproducible and accurate 13 , the methodological aspects of research 14,15 may differ and studies generally depend on weighted analysis to assess sample representativeness of census surveys. To the best of our knowledge, studies comparing the results of telephone and face-to-face interviewing techniques for assessing physical activity indicators have not yet been carried out.

The objective of this study was to compare estimates of prevalence of physical activity indicators and associated sociodemographic factors among adults in a state capital in the South of
Brazil obtained from surveys by telephone and face-to-face interviews.

\section{Methods}

Research using face-to-face interviews consisted of a cross-sectional population-based study carried out between September 2009 and January 2010 using data from the EpiFloripa study which investigated the health conditions of a representative sample of adults in Florianópolis, capital of the State of Santa Catarina. Florianópolis occupies first place in the Human Development Index (HDI) ranking in Brazil (http:/ /www. pnud.org.br/atlas/ranking/IDH-M\%2091\%20 00\%20Ranking\%20decrescente\%20 (pelos\%20 dados\%20de\%202000).htm, accessed on 18/ Aug/2011).

The following parameters were used to determine the minimum sample size needed: unknown prevalence of the different outcomes of the inquiry (50\%); $95 \%$ confidence interval $(95 \% \mathrm{CI})$; sampling error of plus or minus four percentage points; a design effect of two with additional $10 \%$ for losses; $15 \%$ was added for adjusted analysis for potential confounders. The sample size after rounding was 2,016.

The sampling process was carried out in two stages. The first stage consisted of organizing 420 urban areas of Florianópolis adopted by the 2000 Demographic Census (http://www.ibge.gov.br) in ascending order according to head of the household income and randomly selecting six areas from each income decile ( $\mathrm{n}=60$ census areas).

In the second stage, the number of households in each census area was updated by field supervisors by counting the number of occupied homes in each selected census area. The number of occupied homes in each area varied between 61 and 810. The areas were reorganized using fusion and division to reduce the coefficient of variation between areas. The initial coefficient of variation was $55 \%$ ( $n=60$ sectors) and decreased to $32 \%$ after adjustment $(\mathrm{n}=63$ areas comprising 16,755 households). Eighteen households were randomly selected from each census area giving a total of 1,134 households. An average of approximately 32 adults from each census area participated in the study. Inverse probability weighting was used to account for the inverse probability of a household being included in the sample.

The face-to-face interviews were undertaken by 35 trained interviewers using a Personal Digital Assistant (PDA) to record information. Quality control of interviews was conducted by randomly checking $15 \%$ of the completed interviews ( $\mathrm{n}=$ 248) from each area. 
The study was approved by the Human Research Ethics Committee of the Santa Catarina Federal University (document number 351/08).

Research using telephone interviews was performed by the Brazilian Ministry of Health through the VIGITEL. The minimum sample size needed to estimate prevalence of different risk factors was calculated as 2,000 individuals aged 18 years and over $(95 \% \mathrm{CI}$; margin of error $=2 \%$ ).

The research sample was systematically selected from 4,800 registered land lines informed by the telephone companies present in the city. The selected lines were then reselected and divided into 25 replicas, each with 200 lines and the same proportion of lines per census area. This process was performed due to difficulties in estimating the proportion of eligible (i.e.: active) land lines; estimates indicate that $69.3 \%$ of households in Florianópolis have land line telephones 11. Phone lines were excluded if they belonged to a company, no longer existed, were out of service, or did not respond to ten calls made at different times on different days. For each eligible line $(n=2,555)$, the users that agreed to participate in the study were asked to confirm the number of individuals aged 18 years and over residing in the household. A total of 1,800 adults participated in the study.

Telephone interviews were carried out from January to December 2009 by a specialized company contracted for the study with 20 interviewers, four supervisors and a coordinator. The team received prior training and was supervised throughout the period of data collection by a researcher from the University of São Paulo and professionals from the Secretary of Health Surveillance of the Brazilian Ministry of Health.

The following weighting procedures were performed: adjustment based on the inverse number of telephone lines in the interviewee's home, to correct for the greater probability of selection of individuals living in households with more than one telephone line; adjustment based on the number of adults living in the household, to correct for the lower probability of participation of individuals living in households with a larger number of adult residents; sample matching based on sociodemographic characteristics. In this procedure the sample was stratified into 36 sociodemographic categories according to gender (male and female), age range (18-24, 25-34, $35-44,45-54,55-64$ and $\geq 65$ years) and educational attainment $(0-8,9-11$ and $\geq 12$ complete years of study). The same classification was then carried out for the population of Florianópolis based on the 2000 Demographic Census 16. The weighting factor consisted of the ratio between the relative frequencies of individuals from the
2000 Demographic Census and the telephone interview sample in each of the 36 sociodemographic categories.

The VIGITEL was approved by the National Human Research Ethics Committee of the Brazilian Ministry of Health. Since this was a telephone survey, verbal consent was obtained instead of written informed consent.

The questions asked in the face-to-face and telephone interviews were identical in order and format and corresponded to the questions from the physical activity section assessed by the 2009 VIGITEL 12 . Sufficient leisure time physical activity was considered as at least 30 minutes of light to moderate activity a day, at least five days a week, or at least 20 minutes of vigorous physical activity a day, at least three days a week, as recommended by the World Health Organization (WHO) at the time of the study 17. Light to moderate physical activities included walking, walking on a treadmill, weight training, water aerobics, general gymnastics, swimming, martial arts, cycling and volley-ball. Vigorous physical activities included running, running on a treadmill, gymnastic aerobics, football, basketball and tennis 12. This indicator was assessed by the questions: "Have you done any kind of physical activity or sport in the last three months?"; "What main physical exercise or sport do you do on a regular basis?"; "Do you exercise at least once a week?"; "How many days a week do you usually do physical exercise or sport?"; and “How long do you exercise for on the days that you do physical activity?".

Those individuals who answered within the following activity categories were considered physically inactive: had not practiced leisure time physical activities in the last three months; did not carry out physically demanding tasks at work (did not walk much, did not carry weight and did not practice any equivalent physical activity ); did not go to work on foot or by bicycle; and were not responsible for most of the housework.

Individuals who practiced physical activity in their leisure time (according to the above criteria) and/or who went to work or school/college on foot or by bicycle (spending at least 30 minutes a day on the activity), were considered sufficiently active in their leisure and/or commuting time. This indicator was assessed based on the answers to the questions regarding leisure time physical activity cited above and to four questions about commuting to work and/or school/college: "Do you go to work on foot or by bicycle?"; "How much time do you spend on this journey (on foot or by bicycle)?"; "Do you currently attend a school/college or other educational facility or take somebody to school/college or other educational facility?"; 
and "Do you go to school/college or other educational facility on foot or by bicycle?".

The following sociodemographic indicators were assessed: gender (male and female); age (20-29; $30-39$; $40-49$ or 50-59 years); marital status (living with or without a partner) and educational level $(0-4 ; 5-8 ; 9-11$ or $\geq 12$ complete years of study).

For the purpose of comparing estimates of physical activity obtained from the face-to-face and telephone interviews, all subjects outside the 20 to 59 age range were excluded. Data analysis was performed using the Stata statistical software, version 11.0 (Stata Corp., College Station, USA). Descriptive statistics were used to estimate prevalence and $95 \% \mathrm{CI}$ for categorical variables. The numerical variables were presented as averages. An unadjusted analysis was performed to compare the factors associated with level of physical activity using Wald tests for heterogeneity (for nominal categorical variables) and linear trend (ordinal categorical variables). Poisson regression with robust variation was used for the adjusted analysis to estimate prevalence ratio as effect measures. Data was analyzed separately due to the different sample weighting of each study. The "svy" command for complex data and a "backward" selection strategy with a critical level of $\mathrm{p} \leq 0.20$ were used to control confounding variables. In the regression models, demographic variables (gender, age and current marital status) were initially included, followed by social variables (educational level) and the outcomes were adjusted for sociodemographic variables.

\section{Results}

Face-to-face interviews were conducted with 1,720 adults from a total initial sample of 2,016 eligible subjects $(85.3 \%)$, while telephone interviews were conducted with 2,011 individuals from an initial sample of 2,555 eligible subjects (78.7\%). With regard to telephone interviews, after excluding individuals aged $\leq 19$ and $\geq 60$ years ( $\mathrm{n}=536$ ), the final sample size was 1,475 .

Table 1 shows the sociodemographic characteristics of both samples. Over half of the interviewees were women and lived with a partner. The average age of the telephone interview sample and face-to-face interview sample was 36 years $(95 \% \mathrm{CI}$ : $35.1 ; 36.8)$ and 37.3 years $(95 \% \mathrm{CI}$ :

Table 1

Sociodemographic characteristics of the telephone and face-to-face interview samples. Florianópolis, Santa Catarina State, Brazil, 2009.

\begin{tabular}{|c|c|c|c|c|c|c|}
\hline \multirow[t]{2}{*}{ Variable } & \multicolumn{3}{|c|}{ Telephone interview $(n=1,475)$} & \multicolumn{3}{|c|}{ Face-to-face interview ( $n=1,720)$} \\
\hline & n & $\%$ & $95 \% \mathrm{Cl}$ & $\mathbf{n}$ & $\%$ & $95 \% \mathrm{Cl}$ \\
\hline \multicolumn{7}{|l|}{ Gender } \\
\hline Male & 614 & 47.1 & $43.3 ; 50.9$ & 761 & 44.7 & $42.4 ; 46.9$ \\
\hline Female & 861 & 52.9 & $49.1 ; 56.7$ & 959 & 55.3 & $53.1 ; 57.6$ \\
\hline \multicolumn{7}{|l|}{ Age (years) } \\
\hline $20-29$ & 331 & 33.5 & $29.3 ; 37.6$ & 540 & 33.4 & $28.9 ; 38.1$ \\
\hline $30-39$ & 364 & 27.6 & $24.3 ; 30.9$ & 392 & 23.4 & $20.7 ; 26.1$ \\
\hline $40-49$ & 428 & 24.4 & $21.6 ; 27.1$ & 438 & 25.2 & $22.0 ; 28.4$ \\
\hline $50-59$ & 352 & 14.6 & $12.6 ; 16.6$ & 350 & 17.9 & $15.5 ; 20.4$ \\
\hline \multicolumn{7}{|l|}{ Marital status * } \\
\hline Without a partner & 694 & 47.4 & $43.5 ; 51.2$ & 677 & 40.2 & $36.7 ; 43.8$ \\
\hline With a partner & 770 & 52.6 & $48.8 ; 56.5$ & 1043 & 59.8 & $56.2 ; 63.3$ \\
\hline \multicolumn{7}{|c|}{ Educational level (years) ** } \\
\hline$\leq 4$ & 98 & 10.7 & $8.2 ; 13.2$ & 161 & 8.0 & $5.8 ; 10.1$ \\
\hline $5-8$ & 186 & 28.4 & $24.0 ; 32.8$ *** & 253 & 13.7 & $10.8 ; 16.5$ \\
\hline $9-11$ & 483 & 30.2 & $27.2 ; 33.3$ & 568 & 33.7 & $29.1 ; 38.4$ \\
\hline$\geq 12$ & 708 & 30.7 & $27.9 ; 33.5$ *** & 737 & 44.6 & $37.7 ; 51.5$ \\
\hline
\end{tabular}

95\% Cl: 95\% confidence interval.

*Variable with more missing data in telephone interview $(n=11)$;

** Variable with more missing data in face-to-face interview $(n=1)$;

*** Statistically significant difference. 
36.2; 38.5), respectively. No significant statistical differences were observed between the two samples. The level of education was higher among the individuals interviewed face-to-face and this difference was statistically significant. No significant difference was found between estimates for physical activity indicators (Figure 1).

Table 2 presents a description of physical activity indicators by sociodemographic characteristics for each sample. No significant difference was found between the sociodemographic categories of the samples with respect to the prevalence rate of sufficient leisure time physical activity and sufficient leisure time and/or commuting physical activity. Prevalence of physical inactivity in men and younger adults (20-29 year age group) without a partner and with a high level of education ( $\geq 12$ years of study) was higher in all of the abovementioned categories in the telephone interview sample. No significant differences were observed with respect to the remaining categories of age and educational level.

The adjusted analysis showed an association between sufficient leisure time physical activity and being male in both samples (telephone interviews: $\mathrm{PR}=1.56$; 95\%CI: $1.11 ; 2.18$ and faceto-face interviews: $\mathrm{PR}=1.55$; $95 \% \mathrm{CI}: 1.23$; 1.95 ) (Table 3). A direct association, with similar mag- nitude of effect, was found between sufficient leisure time physical activity and educational level in both samples. Neither of the studies showed a significant statistical association between age and marital status and sufficient leisure time physical activity.

The prevalence of sufficient leisure time and/ or commuting physical activity was lower among younger members of the telephone interview sample $(p=0.04)$ and among members of the face-to-face interview sample with a partner $(\mathrm{p}=$ 0.003). Neither of the studies showed a significant association between leisure time and/or commuting physical activity and the remaining sociodemographic variables (Table 3 ).

Men in the telephone interview sample were $74 \%$ more likely to be physically inactive in the four domains, while in the face-to-face interview sample prevalence of inactivity was greater in older individuals $(p<0.001)$ and those with a partner $(\mathrm{p}=0.05)$.

\section{Discussion}

This study shows that the two interview techniques yielded generally similar results regarding physical activity indicators. After the inclusion

Figure 1

Comparison of the estimates of prevalence of physical activity indicators in adults obtained using telephone and face-to-face interviews. Florianópolis, Santa Catarina State, Brazil, 2009.

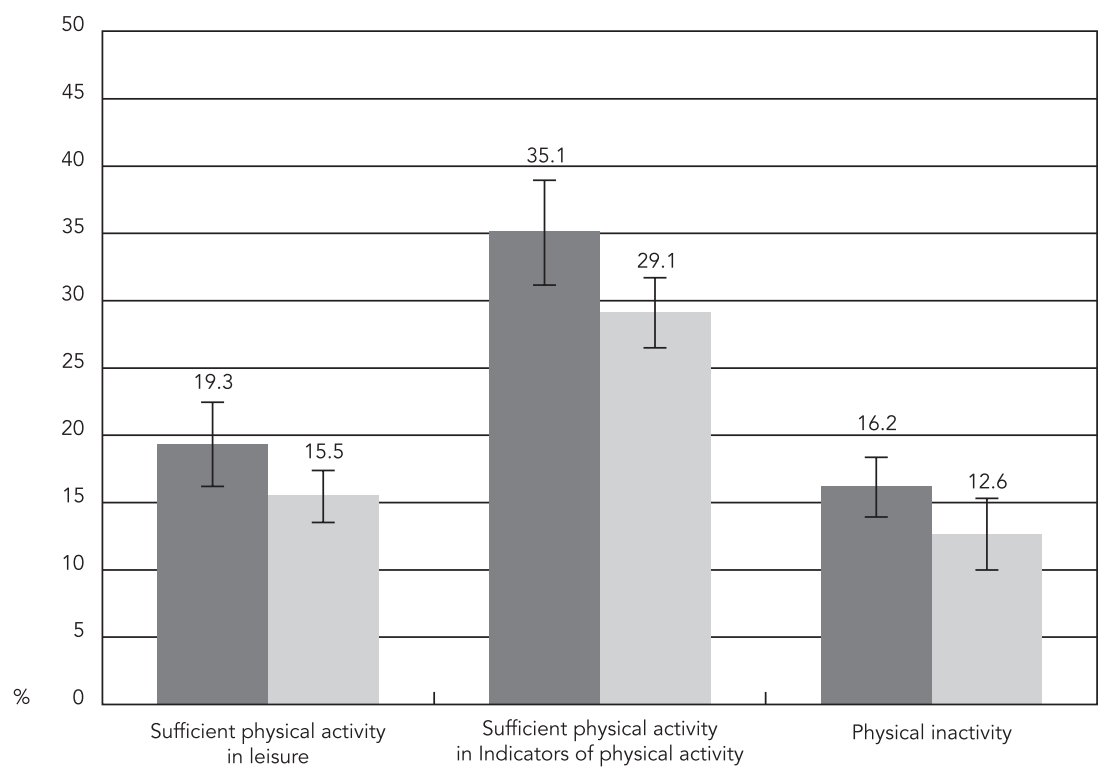

Telephone interview

Face-to-face interview

to 
Table 2

Description of physical activity indicators by sociodemographic characteristics. Florianópolis, Santa Catarina State, Brazil, 2009.

\begin{tabular}{|c|c|c|c|c|c|c|}
\hline \multirow[t]{2}{*}{ Variable } & \multicolumn{3}{|c|}{ Telephone interview $(n=1,475)$} & \multicolumn{3}{|c|}{ Face-to-face interview $(n=1,720)$} \\
\hline & $n$ & $\%$ & $95 \mathrm{Cl} \%$ & $n$ & $\%$ & $95 \% \mathrm{Cl}$ \\
\hline \multicolumn{7}{|l|}{ Gender } \\
\hline Male & 143 & 23.9 & $19.3 ; 28.4$ & 145 & 19.3 & $16.3 ; 22.2$ \\
\hline Female & 146 & 15.3 & $11.0 ; 19.6$ & 117 & 12.5 & $10.2 ; 14.8$ \\
\hline \multicolumn{7}{|l|}{ Age (years) } \\
\hline $20-29$ & 74 & 22.2 & $14.8 ; 29.6$ & 89 & 17.1 & $14.0 ; 20.1$ \\
\hline $30-39$ & 71 & 19.0 & $13.9 ; 24.1$ & 55 & 14.3 & $10.4 ; 18.1$ \\
\hline $40-49$ & 83 & 18.3 & $13.9 ; 22.6$ & 60 & 13.6 & $10.2 ; 17.0$ \\
\hline $50-59$ & 61 & 15.2 & $10.3 ; 20.0$ & 58 & 17.0 & $12.1 ; 21.9$ \\
\hline \multicolumn{7}{|l|}{ Marital status } \\
\hline With a partner & 132 & 17.5 & $14.0 ; 21.1$ & 146 & 13.9 & $11.4 ; 16.3$ \\
\hline \multicolumn{7}{|c|}{ Educational level (years) } \\
\hline$\leq 4$ & 8 & 8.5 & $1.7 ; 15.3$ & 12 & 7.4 & $2.2 ; 12.5$ \\
\hline $5-8$ & 28 & 19.7 & $10.7 ; 28.7$ & 29 & 11.0 & $7.1 ; 15.0$ \\
\hline $9-11$ & 87 & 17.6 & $13.5 ; 21.6$ & 80 & 13.3 & $10.5 ; 16.1$ \\
\hline$\geq 12$ & 166 & 24.5 & $20.9 ; 28.2$ & 141 & 20.1 & $16.8 ; 23.3$ \\
\hline \multicolumn{7}{|c|}{ Sufficient leisure time and/or commuting physical activity } \\
\hline \multicolumn{7}{|l|}{ Gender } \\
\hline Male & 274 & 37.4 & $31.8 ; 42.9$ & 190 & 28.9 & $25.1 ; 32.8$ \\
\hline Female & 208 & 33.1 & $27.9 ; 38.3$ & 200 & 29.2 & $25.2 ; 33.1$ \\
\hline \multicolumn{7}{|l|}{ Age (years) } \\
\hline $20-29$ & 131 & 42.4 & $33.8 ; 51.1$ & 140 & 32.3 & $28.6 ; 36.1$ \\
\hline $30-39$ & 115 & 32.4 & $26.2 ; 38.6$ & 89 & 26.5 & $20.5 ; 32.4$ \\
\hline $50-59$ & 105 & 28.0 & $21.9 ; 34.1$ & 64 & 30.2 & $23.7 ; 36.8$ \\
\hline \multicolumn{7}{|l|}{ Marital status } \\
\hline Without a partner & 256 & 39.5 & $33.2 ; 45.9$ & 179 & 34.1 & $29.7 ; 38.5$ \\
\hline With a partner & 222 & 31.0 & $26.7 ; 35.3$ & 211 & 25.5 & $22.3 ; 28.7$ \\
\hline \multicolumn{7}{|c|}{ Educational level (years) } \\
\hline$\leq 4$ & 31 & 29.7 & $19.2 ; 40.2$ & 26 & 21.0 & $10.4 ; 31.6$ \\
\hline $5-8$ & 65 & 41.4 & $30.9 ; 51.9$ & 51 & $29 . .4$ & $21.0 ; 37.8$ \\
\hline $9-11$ & 149 & 31.2 & $26.2 ; 36.2$ & 130 & 28.3 & $24.0 ; 32.5$ \\
\hline$\geq 12$ & 237 & 35.0 & $30.1 ; 39.0$ & 183 & 30.6 & $26.1 ; 35.1$ \\
\hline \multicolumn{7}{|l|}{ Physical inactivity } \\
\hline \multicolumn{7}{|l|}{ Gender } \\
\hline Male & 152 & 20.9 & $17.2 ; 24.6$ * & 91 & 12.6 & $9.4 ; 15.9$ \\
\hline Female & 130 & 12.0 & $9.5 ; 14.5$ & 112 & 12.5 & $9.1 ; 15.9$ \\
\hline \multicolumn{7}{|l|}{ Age (years) } \\
\hline $20-29$ & 74 & 16.3 & $12.0 ; 20.7$ * & 36 & 6.8 & $3.9 ; 9.8$ \\
\hline $30-39$ & 72 & 16.0 & $11.9 ; 20.2$ & 50 & 14.1 & $10.1 ; 18.1$ \\
\hline $40-49$ & 75 & 14.3 & $10.6 ; 17.9$ & 54 & 13.1 & $9.1 ; 17.1$ \\
\hline $50-59$ & 61 & 19.4 & $13.6 ; 25.3$ & 63 & 20.5 & $15.3 ; 25.7$ \\
\hline \multicolumn{7}{|l|}{ Marital status } \\
\hline Without a partner & 142 & 17.4 & $13.9 ; 20.9$ * & 59 & 9.0 & $6.3 ; 11.7$ \\
\hline With a partner & 139 & 15.1 & $12.3 ; 18.0$ & 144 & 14.9 & $11.5 ; 18.4$ \\
\hline
\end{tabular}

(continues) 


\begin{tabular}{|c|c|c|c|c|c|c|}
\hline \multirow[t]{2}{*}{ Variable } & \multicolumn{3}{|c|}{ Telephone interview $(n=1,475)$} & \multicolumn{3}{|c|}{ Face-to-face interview $(n=1,720)$} \\
\hline & $\mathrm{n}$ & $\%$ & $95 \mathrm{Cl} \%$ & $\mathrm{n}$ & $\%$ & $95 \% \mathrm{Cl}$ \\
\hline \multicolumn{7}{|c|}{ Physical inactivity } \\
\hline \multicolumn{7}{|c|}{ Educational level (years) } \\
\hline$\leq 4$ & 9 & 9.3 & $2.7 ; 15.9$ & 26 & 19.3 & $11.5 ; 27.2$ \\
\hline $5-8$ & 10 & 4.9 & $1.7 ; 8.1$ & 30 & 13.3 & $8.0 ; 18.7$ \\
\hline $9-11$ & 73 & 15.9 & $12.0 ; 19.8$ & 66 & 12.0 & $8.2 ; 15.8$ \\
\hline$\geq 12$ & 190 & 29.3 & $25.4 ; 33.1$ * & 81 & 11.6 & $8.7 ; 14.5$ \\
\hline
\end{tabular}

95\% Cl: $95 \%$ confidence interval.

* Statistically significant difference between these results and the results obtained from face-to-face interviews.

of the variable leisure time and/or commuting physical activity in 2009, the VIGITEL 12 now adopts three indicative measures of physical activity. This initiative follows the tendency among international agencies, such as the WHO 18 and the U.S. Department of Health and Human Services 19 , to promote different domains of physical activity as a way of meeting recommended health standards.

No significant statistical differences in prevalence of sufficient leisure time physical activity, sufficient leisure time and/or commuting physical activity and physical inactivity in the four domains were found between the interview techniques. The adoption of a physically active lifestyle (commuting, occupational, household, leisure time) differs according to socioeconomic status 4,10,20 and therefore this finding may be explained by the similarity between the sociodemographic characteristics of the samples. Another study carried out in Brazil that compared the results of face-to-face and telephone interview techniques used for administering the International Physical Activity Questionnaire with a group of adults found a very high correlation between the two techniques (kappa coefficient 0.69) 21.

Research focused primarily on leisure time physical activity domains because activity in this domain is generally more intense. However, other domains of physical activity can also contribute to a significant reduction in mortality from all causes, particularly cancer and cardiovascular disease 22,23. The proportion of individuals from the telephone and face-to-face interview samples considered physically active during leisure time was $19.3 \%$ and $15.5 \%$, respectively. This proportion is higher than that observed in China (10\%) 24 but lower than in developed counties such as Spain (28.8\%) 25 and the United States (41.9\%) 26. These differences may be explained by environmental and socioeconomic factors. In the present study, the results of both interview techniques showed that men were more physically active during leisure time than women and a direct association was observed between education level and sufficient physical activity. These findings are consistent with other studies $4,8,25,26$ that suggest that men are more active during leisure time due to greater involvement in sports 16,26, while women carry the burden of a double work day that hinders their engagement in recreational physical activity.

The contribution of leisure time physical activity to total energy expenditure from daily physical activity is lower than other domains 4,27. Physical activity during commuting makes up a significant proportion of total physical activity among the population, especially in developing countries 28,29 . The use of leisure time physical activity as a sole indicator to evaluate compliance with recommended levels of physical activity leads to a reduction in the association between sociodemographic characteristics and prevalence of sufficient leisure time and/or commuting physical activity as an indicator of the total physical activity. Estimates of prevalence of sufficient leisure time and/or commuting physical activity based on data from telephone interviews and face-to-face interviews were similar $35.1 \%$ and $29.1 \%$, respectively). However, these findings differ considerably from those observed in studies carried out in the United States 26 and China ${ }^{24}$ which state that five out of 10 adults are physically active when leisure and commuting domains are considered together. Prevalence by population subgroups was very similar, reflecting only small differences in rates according to sociodemographic characteristics. No significant differences were found between the two interview techniques.

The two interview techniques yielded very similar prevalence rates of physical inactivity based on physical inactivity in all four domains. 
Table 3

Sociodemographic factors associated with physical activity indicators by interview technique (telephone and face-to-face). Florianópolis, Santa Catarina State, Brazil, 2009

\begin{tabular}{|c|c|c|c|c|c|c|c|c|c|c|c|c|}
\hline \multirow[t]{3}{*}{ Variable } & \multicolumn{6}{|c|}{ Telephone interview $(n=1,475)$} & \multicolumn{6}{|c|}{ Face-to-face interview $(n=1,720)$} \\
\hline & \multicolumn{3}{|c|}{ Crude analysis } & \multicolumn{3}{|c|}{ Adjusted analysis * } & \multicolumn{3}{|c|}{ Crude analysis } & \multicolumn{3}{|c|}{ Adjusted analysis * } \\
\hline & PR & $95 \% \mathrm{Cl}$ & p-value & PR & $95 \% \mathrm{Cl}$ & $p$-value & PR & $95 \% \mathrm{Cl}$ & p-value & PR & $95 \% \mathrm{Cl}$ & p-value \\
\hline \multicolumn{13}{|l|}{$\begin{array}{l}\text { Sufficient leisure time physical } \\
\text { activity }\end{array}$} \\
\hline Gender & & & $0.01 * \star$ & & & 0.01 ** & & & $<0.001$ ** & & & $<0.001$ ** \\
\hline Male & 1.56 & $1.11 ; 2.19$ & & 1.56 & $1.11 ; 2.18$ & & 1.54 & $1.22 ; 1.94$ & & 1.55 & $1.23 ; 1.95$ & \\
\hline Female & 1.00 & & & 1.00 & & & 1.00 & & & 1.00 & & \\
\hline Age (years) & & & $0.13 * \star \star$ & & & 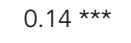 & & & $0.69 * \star \star$ & & & $0.73 * \star \star$ \\
\hline $20-29$ & 1.00 & & & 1.00 & & & 1.00 & & & 1.00 & & \\
\hline $30-39$ & 0.86 & $0.56 ; 1.31$ & & 0.84 & $0.55 ; 1.29$ & & 0.84 & $0.64 ; 1.09$ & & 0.95 & $0.68 ; 1.31$ & \\
\hline $40-49$ & 0.82 & $0.55 ; 1.24$ & & 0.83 & $0.55 ; 1.26$ & & 0.80 & $0.59 ; 1.09$ & & 0.91 & $0.65 ; 1.27$ & \\
\hline $50-59$ & 0.68 & $0.43 ; 1.08$ & & 0.68 & $0.43 ; 1.07$ & & 1.00 & $0.69 ; 1.43$ & & 1.11 & $0.78 ; 1.58$ & \\
\hline Marital status & & & $0.21 * \star$ & & & $0.43 * \star$ & & & $0.07 * \star$ & & & $0.06 * \star$ \\
\hline Without a partner & 1.00 & & & 1.00 & & & 1.00 & & & 1.00 & & \\
\hline With a partner & $0, .81$ & $0.59 ; 1.12$ & & 0.88 & $0.64 ; 1.20$ & & 0.77 & $0.58 ; 1.02$ & & 0.77 & $0.58 ; 1.01$ & \\
\hline Educational level (years) & & & 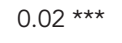 & & & $0.04 * \star \star$ & & & $<0.001 \star \star \star$ & & & $<0.001 \star \star \star$ \\
\hline$\leq 4$ & 1.00 & & & 1.00 & & & 1.00 & & & 1.00 & & \\
\hline $5-8$ & 2.31 & $0.93 ; 5.74$ & & 2.02 & $0.82 ; 4.94$ & & 1.50 & $0.66 ; 3.39$ & & 1.53 & $0.68 ; 3.47$ & \\
\hline $9-11$ & 2.06 & $0.91 ; 4.69$ & & 1.83 & $0.81 ; 4.16$ & & 1.80 & $0.88 ; 3.68$ & & 1.76 & $0.86 ; 3.59$ & \\
\hline$\geq 12$ & 2.88 & $1.29 ; 6.43$ & & 2.58 & $1.16 ; 5.77$ & & 2.73 & $1.32 ; 5.66$ & & 2.67 & $1.29 ; 5.53$ & \\
\hline \multicolumn{13}{|l|}{$\begin{array}{l}\text { Sufficient leisure time and/or } \\
\text { commuting physical activity }\end{array}$} \\
\hline \multicolumn{13}{|l|}{ Gender } \\
\hline Male & 1.13 & $0.91 ; 1.40$ & 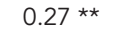 & 1.12 & $0.90 ; 1.38$ & 0.30 ** & 0.99 & $0.81 ; 1.22$ & 0.94 ** & 1.01 & $0.82 ; 1.25$ & 0.92 ** \\
\hline Female & 1.00 & & & 1.00 & & & 1.00 & & & 1.00 & & \\
\hline Age (years) & & & $0.008 * \star \star$ & & & $0.04 * \star \star$ & & & $0.34 * \star \star$ & & & 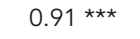 \\
\hline $20-29$ & 1.00 & & & 1.00 & & & 1.00 & & & 1.00 & & \\
\hline $30-39$ & 0.76 & $0.58 ; 1.01$ & & 0.81 & $0.61 ; 1.08$ & & 0.82 & $0.66 ; 1.02$ & & 0.92 & $0.73 ; 1.15$ & \\
\hline $40-49$ & 0.76 & $0.59 ; 0.99$ & & 0.81 & $0.62 ; 1.07$ & & 0.82 & $0.63 ; 1.07$ & & 0.91 & $0.69 ; 1.20$ & \\
\hline $50-59$ & 0.66 & $0.49 ; 0.89$ & & 0.71 & $0.52 ; 0.96$ & & 0.94 & $0.72 ; 1.21$ & & 1.02 & $0.78 ; 1.34$ & \\
\hline Marital status & & & 0.02 ** & & & 0.14 ** & & & 0.003 ** & & & $0.003 * \star$ \\
\hline Without a partner & 1.00 & & & 1.00 & & & 1.00 & & & 1.00 & & \\
\hline With a partner & 0.78 & $0.63 ; 0.97$ & & 0.85 & $0.69 ; 1.05$ & & 0.75 & $0.62 ; 0.90$ & & 0.75 & $0.62 ; 0.90$ & \\
\hline Educational level (years) & & & 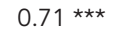 & & & $0.46 * \star \star$ & & & $0.23 * \star \star$ & & & 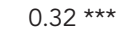 \\
\hline$\leq 4$ & 1.00 & & & 1.00 & & & 1.00 & & & 1.00 & & \\
\hline $5-8$ & 1.39 & $0.91 ; 2.14$ & & 1.27 & $0.83 ; 1.95$ & & 1.40 & $0.77 ; 2.55$ & & 1.44 & $0.79 ; 2.61$ & \\
\hline $9-11$ & 1.05 & $0.72 ; 1.54$ & & 0.93 & $0.62 ; 1.39$ & & 1.35 & $0.81 ; 2.23$ & & 1.32 & $0.81 ; 2.16$ & \\
\hline$\geq 12$ & 1.18 & $0.82 ; 1.70$ & & 1.07 & $0.73 ; 1.58$ & & 1.46 & $0.85 ; 2.51$ & & 1.42 & $0.84 ; 2.40$ & \\
\hline \multicolumn{13}{|l|}{ Physical inactivity } \\
\hline Gender & & & $<0.001$ ** & & & $<0.001$ ** & & & 0.94 ** & & & 0.94 ** \\
\hline Male & 1.74 & $1.32 ; 2.30$ & & 1.74 & $1.32 ; 2.30$ & & 1.01 & $0.73 ; 1.40$ & & 1.01 & $0.73 ; 1.40$ & \\
\hline Female & 1.00 & & & 1.00 & & & 1.00 & & & 1.00 & & \\
\hline Age (years) & & & $0.73^{\star \star \star}$ & & & $0.39 \star \star \star$ & & & $<0.001 \star \star \star$ & & & $<0.001 \star \star \star$ \\
\hline $20-29$ & 1.00 & & & 1.00 & & & 1.00 & & & 1.00 & & \\
\hline $30-39$ & 0.98 & $0.68 ; 1.42$ & & 1.02 & $0.70 ; 1.49$ & & 2.06 & $1.31 ; 3.24$ & & 1.83 & $1.16 ; 2.89$ & \\
\hline $40-49$ & 0.87 & $0.61 ; 1,26$ & & 0.96 & $0.66 ; 1.39$ & & 1.90 & $1.24 ; 2.95$ & & 1.70 & $1.07 ; 2.69$ & \\
\hline $50-59$ & 1.19 & $0.80 ; 1.78$ & & 1.27 & $0.86 ; 1.87$ & & 3.00 & $1.86 ; 4.83$ & & 2.70 & $1.62 ; 4.50$ & \\
\hline
\end{tabular}

(continues) 


\begin{tabular}{|c|c|c|c|c|c|c|c|c|c|c|c|c|}
\hline \multirow[t]{3}{*}{ Variable } & \multicolumn{6}{|c|}{ Telephone interview $(n=1,475)$} & \multicolumn{6}{|c|}{ Face-to-face interview $(n=1,720)$} \\
\hline & \multicolumn{3}{|c|}{ Crude analysis } & \multicolumn{3}{|c|}{ Adjusted analysis * } & \multicolumn{3}{|c|}{ Crude analysis } & \multicolumn{3}{|c|}{ Adjusted analysis * } \\
\hline & PR & $95 \% \mathrm{Cl}$ & p-value & PR & $95 \% \mathrm{Cl}$ & $p$-value & PR & $95 \% \mathrm{Cl}$ & p-value & PR & $95 \% \mathrm{Cl}$ & p-value \\
\hline \multicolumn{13}{|l|}{ Physical inactivity } \\
\hline Marital status & & & 0.31 ** & & & $0.33 * \star$ & & & $0.002 * \star$ & & & 0.05 ** \\
\hline Without a partner & 1.00 & & & 1.00 & & & 1.00 & & & 1.00 & & \\
\hline With a partner & 0.87 & $0.66 ; 1.14$ & & 0.87 & $0.67 ; 1.15$ & & 1.66 & $1.21 ; 2.28$ & & 1.41 & $1.00 ; 1.97$ & \\
\hline Educational level (years) & & & $<0.001 * * \star$ & & & $<0.001 \star \star \star$ & & & $0.09 * * \star$ & & & $0.45^{* \star *}$ \\
\hline$\leq 4$ & 1.00 & & & 1.00 & & & 1.00 & & & 1.00 & & \\
\hline $5-8$ & 0.53 & $0.20 ; 1.36$ & & 0.48 & $0.19 ; 1.24$ & & 0.69 & $0.44 ; 1.07$ & & 0.75 & $0.48 ; 1.18$ & \\
\hline $9-11$ & 1.71 & $0.81 ; 3.58$ & & 1.61 & $0.77 ; 3.38$ & & 0.62 & $0.39 ; 0.97$ & & 0.77 & $0.49 ; 1.20$ & \\
\hline$\geq 12$ & 3.14 & $1.54 ; 6.39$ & & 2.91 & $1.43 ; 5.92$ & & 0.60 & $0.38 ; 0.94$ & & 0.76 & $0.48 ; 1.20$ & \\
\hline
\end{tabular}

95\% Cl: 95\% confidence interval; PR: prevalence ratio.

* Adjusted analysis for the variables sex, age, marital status (first level) and education (second level);

** Wald test for heterogeneity;

$* \star *$ Wald test for linear trend.

Physical inactivity was slightly higher among younger and more educated individuals in the telephone interview sample. However, the two interview techniques showed divergent results suggesting that errors occurred in estimates of associated factors. Men and more educated individuals from the telephone research sample were more inactive, whereas in the face-to-face interview sample older individuals and those with a partner were more likely to be physically inactive. A literature review 30 suggests that physical activity is generally greater in younger married men with a higher level of education. However, it should be emphasized that the majority of studies included in this review focused exclusively on the physical activity in leisure time domain, where the influence of sociodemographic characteristics on prevalence of physical activity is more pronounced.

In a study in China 4 that grouped activity into commuting, occupational, household and leisure time, no significant differences in weekly energy expenditure were observed between genders.

Possible explanations for differences between the factors associated with physical activity under the two interview techniques are greater access to landline telephones among certain population subgroups 31 , the long duration of the data collection process under the telephone interview technique (seasonality) and the probability of the occurrence of random errors due to the numbers of variables which comprise physical inactivity.

This research is unique in that it provides previously unavailable data. Although some indicators evaluated by the VIGITEL system have already been analyzed 32,33,34, no previous comparison of the physical activity indicators used by this monitoring system had been carried out using telephone monitoring and household interviews. However, the present study has certain limitations that need to be taken into account. Florianópolis has one of the highest coverage rates for landline telephones among Brazilian state capitals 11. Positive results observed with regard to prevalence estimates for physical activity indicators may not be repeatable in cities with lower coverage and this situation needs to be addressed. In addition, the time spent collecting data through telephone interviews may have been affected by the time of year that the study was carried out. Finally, data was collected in 2009 and the current scenario for physical activity indicators may be different.

Monitoring the factors associated with health behaviors is essential to designing adequate public policies. The recent initiative in Brazil to monitor risk and protection factors related to chronic disease using telephone interviews is an interesting alternative to reduce the costs and time involved in data collection in such a large country. The prevalence rates of general and specific physical activity indicators by sociodemographic characteristics were generally similar under the two interview techniques analyzed by this study. It is recommended that future research should be carried out to compare physical activity indicators with other health indicators in cities covered by the VIGITEL system where a lower percentage of households have access to landlines. 


\section{Resumen}

El objetivo de este estudio fue comparar la prevalencia de indicadores de actividad física y factores sociodemográficos, asociados a una investigación por teléfono y entrevistas cara a cara. Los datos de la investigación transversal poblacional con adultos de Florianópolis, Santa Catarina, Brasil, se contrastaron con los recogidos por el sistema Vigitel. La encuesta por entrevista telefónica (1.475) y las entrevistas cara a cara (1.720) mostraron diferencias significativas en la prevalencia de una suficiente actividad física en el ámbito de ocio (15,5 vs. 19,3), suficiente actividad física en el ocio o el desplazamiento $(35,1$ versus 29,1$)$ y la inactividad física (12,6 versus 16,2), respectivamente. En la investigación de factores sociodemográficos, asociados con la actividad física en el ocio o el desplazamiento, y la inactividad física, se observaron algunas diferencias entre las encuestas. Se concluye que la mayoría de las estimaciones de prevalencia y factores asociados con los indicadores de actividad física diferente fueron similares entre las dos encuestas.

Actividad Motora; Autoinforme; Entrevista; Teléfono

\section{References}

1. Dumith SC, Domingues MR, Gigante D. Epidemiologia das atividades físicas praticadas no tempo de lazer por adultos do Sul do Brasil. Rev Bras Epidemiol 2009; 12:646-58.

2. Troiano RP, Berrigan D, Dodd KW, Mâsse LC, Tilert T, McDowell M. Physical activity in the United States measured by accelerometer. Med Sci Sports Exerc 2008; 40:181-8.

3. Barnett TA, Gauvin L, Craig CL, Katzmarzyk PT. Distinct trajectories of leisure time physical activity and predictors of trajectory class membership: a 22 year cohort study. Int J Behav Nutr Phys Act 2008; 5:57.

4. Nang EEK, Khoo EY, Salim A, Tai ES, Lee J, Van Dam RM. Patterns of physical activity in different domains and implications for intervention in a multi-ethnic Asian population: a cross-sectional study. BMC Public Health 2010; 10:644.

5. Ali SM, Lindstrom M. Psychosocial work conditions, unemployment, and leisure-time physical activity: a population-based study. Scand J Public Health 2006; 34:209-16.

\section{Contributors}

G. F. Del Duca was responsible for study conception and statistical analysis, and drafted the first version of this manuscript. M. V. Nahas supervised statistical analysis, participated in the drafting of this manuscript, and critically revised this text. D. A. S. Silva, P. C. Hallal and D. C. Malta contributed to the critical revision of this text. M. A. Peres coordinated fieldwork, and critically revised a preliminary version of this text.

\section{Acknowledgments}

G. F. Del Duca is grateful to Capes for providing a scholarship. M. V. Nahas, P. C. Hallal and M. A. A. Peres are grateful to the $\mathrm{CNPq}$ for providing a productive research scholarship. The authors wish to thank CNPq for funding this research.
6. Gast GC, Frenken FJ, van Leest LA, Wendel-Vos GC, Bemelmans WJ. Intra-national variation in trends in overweight and leisure time physical activities in The Netherlands since 1980: stratification according to sex, age and urbanisation degree. Int $\mathrm{J}$ Obes 2007; 31:515-20.

7. Centers for Disease Control and Prevention. Health risks in the United States: Behavioral Risk Factor Surveillance System. At a glance 2010. Atlanta: Centers for Disease Control and Prevention; 2010.

8. Centers for Disease Control and Prevention. Trends in leisure-time physical inactivity by age, sex, and race/ethnicity: United States, 1994-2004. MMWR Morb Mortal Wkly Rep 2005; 54:991-4.

9. Meseguer CM, Galán I, Herruzo R, Rodriguez-Artalejo F. Trends in leisure time and occupational physical activity in the Madrid region, 1995-2008. Rev Esp Cardiol 2011; 64:21-7. 
10. Kahan E, Fogelman Y, Bloch B. Correlations of work, leisure, and sports physical activities and health status with socioeconomic factors: a national study in Israel. Postgrad Med J 2005; 81:262-5.

11. Secretaria de Vigilância em Saúde, Ministério da Saúde. VIGITEL 2006. Vigilância de fatores de risco e proteção para doenças crônicas por inquérito telefônico. Brasília: Ministério da Saúde; 2007.

12. Secretaria de Vigilância em Saúde, Ministério da Saúde. VIGITEL 2009. Vigilância de fatores de risco e proteção para doenças crônicas por inquérito telefônico. Brasília: Ministério da Saúde; 2010.

13. Monteiro CA, Florindo AA, Claro RM, Moura EC. Validade de indicadores de atividade física e sedentarismo obtidos por inquérito telefônico. Rev Saúde Pública 2008; 42:575-81.

14. Florindo AA, Hallal PC, Moura EC, Malta DC. Prática de atividades físicas e fatores associados em adultos, Brasil, 2006. Rev Saúde Pública 2009; 43:65-73.

15. Malta DC, Moura EC, Castro AM, Cruz DKA, Morais Neto OL, Monteiro CA. Padrão de atividade física em adultos brasileiros: resultados de um inquérito por entrevistas telefônicas, 2006. Epidemiol Serv Saúde 2009; 18:7-16.

16. Salles-Costa R, Heilborn ML, Werneck GL, Faerstein E, Lopes CS. Gênero e prática de atividade física de lazer. Cad Saúde Pública 2003; 19 Suppl 2:S325-33.

17. Francisco PMSB, Barros MBA, Segri NJ, Alves MCGP, Cesar CLG, Malta DC. Comparação de estimativas para o auto-relato de condições crônicas entre inquérito domiciliar e telefônico - Campinas (SP), Brasil. Rev Bras Epidemiol 2011;14:5-15.

18. World Health Organization. Global recommendations on physical activity for health. Geneva: World Health Organization; 2010.

19. U.S. Department of Health and Human Services. Physical activity guidelines for Americans: be active, healthy, and happy! Washington DC: U.S. Department of Health and Human Services; 2008.

20. Pitanga FJG, Lessa I, Barbosa PJB, Barbosa SJO, Costa MC, Lopes AS. Fatores sociodemográficos associados aos diferentes domínios da atividade física em adultos de etnia negra. Rev Bras Epidemiol 2012; 15:363-75.

21. Hallal PC, Simões E, Reichert FF, Azevedo MR, Ramos LR, Pratt M, et al. Validity and reliability of the telephone-administered International Physical Activity Questionnaire in Brazil. J Phys Act Health 2010; 7:402-9.

22. Autenrieth CS, Baumert J, Baumeister SE, Fischer B, Peters A, Döring A, et al. Association between domains of physical activity and all-cause, cardiovascular and cancer mortality. Eur J Epidemiol 2011; 26:91-9.

23. Samitz G, Egger M, Zwahlen M. Domains of physical activity and all-cause mortality: systematic review and dose-response meta-analysis of cohort studies. Int J Epidemiol 2011; 40:1382-400.
24. Hu G, Pekkarinen H, Hanninen O, Yu Z, Tian H, Guo Z, et al. Physical activity during leisure and commuting in Tianjin, China. Bull World Health Organ 2002; 80:933-8.

25. Meseguer CM, Galan I, Herruzo R, Zorrilla B, Rodriguez-Artalejo F. Leisure-time physical activity in a southern European mediterranean country: adherence to recommendations and determining factors. Rev Esp Cardiol. 2009; 62:1125-33.

26. Berrigan D, Troiano RP, McNeel T, Disogra C, Ballard-Barbash R. Active transportation increases adherence to activity recommendations. Am J Prev Med 2006; 31:210-6.

27. Livingstone M, Robson P, McCarthy S, Kiely M, Harrington K, Browne P, et al. Physical activity patterns in a nationally representative sample of adults in Ireland. Public Health Nutr 2001; 4:110716.

28. Ku PW, Fox KR, McKenna J, Peng TL. Prevalence of leisure-time physical activity in Taiwanese adults: results of four national surveys, 2000-2004. Prev Med 2006; 43:454-7.

29. Trinh O, Nguyen N, Dibley M, Phongsavan P, Bauman A. The prevalence and correlates of physical inactivity among adults in Ho Chi Minh City. BMC Public Health 2008; 8:204.

30. Trost SG, Owen N, Bauman AE, Sallis JF, Brown W. Correlates of adults' participation in physical activity: review and update. Med Sci Sports Exerc 2002; 34:1996-2001.

31. Azevedo MR, Araújo CL, Silva MC, Hallal PC. Tracking of physical activity from adolescence to adulthood: a population-based study. Rev Saúde Pública 2007; 41:69-75.

32. Bernal R, Silva NN. Cobertura de linhas telefônicas residenciais e vícios potenciais em estudos epidemiológicos. Rev Saúde Pública 2009; 43:421-6.

33. Segri NJ, Francisco PMSB, Alves MCGP, Barros MBA, César CLG, Goldbaum M, et al. Práticas preventivas de detecção de câncer em mulheres: comparação das estimativas dos inquéritos de saúde (ISA-Capital) e vigilância de fatores de risco e proteção para doenças crônicas por inquérito telefônico (VIGITEL - São Paulo). Rev Bras Epidemiol 2011; 14:31-43.

34. Ferreira AD, César CC, Malta DC, Andrade ACS, Ramos CGC, Proietti FA, et al. Validade de estimativas obtidas por inquérito telefônico: comparação entre VIGITEL 2008 e Inquérito Saúde em Beagá. Rev Bras Epidemiol 2011; 14:16-30.

Submitted on $03 /$ Sep/2012

Final version resubmitted on 03/Apr/2013

Approved on 24/Apr/2013 